\title{
Pembelajaran Bahasa Inggris Melalui Siaran Radio Komunitas Balai Budaya Minomartani FM 107,7 MHz
}

\author{
Sharifah Hanidar, Rio Rini Diah Moehkardi \\ Prodi Sastra Inggris, Departemen Bahasa dan Sastra, Fakultas Ilmu Budaya UGM \\ Korespondensi: sharifah@ugm.ac.id
}

Tim Pengabdian kepada Masyarakat:

Adi Sutrisno, Bernadus Hidayat, Mala Hernawati, Moh. Arif Rohman, Ni Gusti Ayu Roselani, Rio Rini Diah Moehkardi, Sharifah Hanidar, Thomas Joko Priyo Sembodo, Tofan Dwi Hardjanto, Alya Salsabila Firdausi, Emma Natasha Octoveria, Heri Widodo, Mathilda Claressa Ragadina, Muhammad Rizky, Mumtazah Minhatul Maula, Nadia Athali, Natrila Femigasari,, Ratri Atha Al Husna, Wenzelando Puandra Purwoko

\begin{abstract}
The community service program conducted by the English Study Program held from April to July, 2019 was the fourth in a series of activities in cooperation with Balai Budaya Minomartani and the community radio station, Balai Budaya Minomartani FM $107.7 \mathrm{MHz}$. It aims to increase the community capacity by training high school students living in Minomartani and its vicinity to become broadcasters of an educational entertainment radio program. In this program, Indonesian folktales in English translation are used as a medium for teaching English through storytelling. In achieving the aim, a two day workshop on radio broadcasting was held at the Faculty of Cultural Sciences, Universitas Gadjah Mada. The resource persons presenting in the workshop are community radio practitioners from the community radio station and lecturers from the English Study Program, Universitas Gadjah Mada. In the workshop, participants learned how to operate audio mixer, tell stories and present material on the radio. The participants were also provided with a module to help them identify language items to teach and select, modify, and convert the folk tales into audio scripts. Under the guidance and supervision of tutors from the English Study Program, the participants selected the language items in the folktales and developed them into teaching materials, made audio scripts and presented them. The participants were recorded reading their scripts. The audio recording was then broadcasted by the community radio station, Balai Budaya Minomartani FM 107.7 MHz. As the community radio is internet-based, the broadcast could be heard world wide. In this way, Indonesian folktales are also promoted to the world.
\end{abstract}

Keywords: community capacity, community radio station, Indonesian folk tales, storytelling, educational entertainment

\begin{abstract}
Abstrak
Pengabdian kepada Masyarakat yang dilaksanakan Prodi Sastra Inggris sejak April-Juli 2019 bekerja sama dengan Balai Budaya Minomartani dan Radio Komunitas Balai Budaya Minomartani FM 107.7 MHz, merupakan yang keempat kalinya dalam serangkaian kegiatan kerjasama. Pengabdian kepada Masyarakat ini bertujuan mengembangkan kapasitas masyarakat dengan melatih siswa SMA/SMK yang tinggal di Minomartani dan sekitarnya untuk menjadi
\end{abstract}


penyiar program pendidikan dan hiburan. Dalam program ini, cerita rakyat Indonesia yang telah diterjemahkan ke dalam bahasa Inggris digunakan sebagai media pembelajaran bahasa Inggris dengan memakai metode storytelling. Untuk mencapai tujuannya, Prodi Sastra Inggris menyelenggarakan workshop yang berlangsung selama dua hari di Fakultas Ilmu Budaya, Universitas Gadjah Mada. Para narasumber merupakan praktisi radio komunitas dan dosendosen Prodi Sastra Inggris, Universitas Gadjah Mada. Para peserta workshop diajarkan bagaimana mengoperasikan audiomixer, bercerita dan menyiarkan materi. Di samping itu, para peserta diberikan modul untuk membantu mereka dalam mengidentifikasi butir bahasa yang akan diajarkan, memilih, memodifikasi dan mengubah cerita rakyat menjadi audio script. Di bawah bimbingan tutor dari Prodi Sastra Inggris, peserta memilih unsur bahasa yang terdapat dalam cerita rakyat dan mengembangkannya menjadi bahan ajar, membuat audio script, membacakannya sambil direkam untuk kemudian disiarkan di radio komunitas Balai Budaya Minomartani FM 107.7 MHz. Karena radio komunitas BBM sudah berbasis internet, siaran ini dapat didengarkan di seluruh dunia sehingga menjadi sarana promosi cerita rakyat Indonesia.

Kata kunci: pemberdayaan masyarakat, radio komunitas, cerita rakyat Indonesia, bercerita, pendidikan dan hiburan

\section{Pendahuluan}

Balai Budaya Minomartani yang beralamat di Tegalrejo RT 32/RW 12 Minomartani, Ngaglik, Sleman merupakan pusat kegiatan seni dan budaya serta tempat berkumpul komunitas Balai Budaya Minomartani (BBM) yang bertujuan untuk melestarikan dan mengembangkan kebudayaan Indonesia, khususnya kebudayaan Jawa. Di samping komunitas BBM, banyak tamu mancanegara mengunjungi BBM untuk belajar seni dan budaya Jawa, bahkan ikut serta mengadakan pementasan di BBM. Kegiatan seni yang digelar di BBM seperti pagelaran wayang, mocopat, dan karawitan disiarkan secara live streaming melalui radio komunitas Balai Budaya Minomartani FM 107,7 MHz yang telah berbasis internet sehingga dapat diakses dan dinikmati oleh pendengar, baik di dalam maupun luar negeri.

Dalam melaksanakan kegiatannya, BBM menjalin kerja sama dengan berbagai pihak, antara lain, Program Studi (Prodi) Sastra Inggris, Universitas Gadjah Mada yang telah berlangsung selama tiga periode. Program-program kerja sama yang sudah dilaksanakan adalah (1) "Pengembangan Motivasi Membaca dalam Bahasa Inggris melalui Cerita Rakyat” pada tahun 2015 yang bertujuan melatih guru-guru pengampu mata pelajaran bahasa Inggris di SD dan SMP dalam hal penggunaan cerita rakyat dan wayang (wayang kancil) untuk meningkatkan motivasi siswa dalam membaca teks berbahasa Inggris. (2) "Pengajaran Bahasa Inggris melalui Siaran Radio Komunitas Periode I" pada tahun 2017 yang bertujuan mengajarkan bahasa Inggris dan meningkatkan minat masyarakat pada bahasa Inggris melalui program siaran radio yang bersifat informatif, edukatif, serta menghibur. (3) "Pengajaran Bahasa Inggris melalui Siaran Radio Komunitas Periode II" pada tahun 2018 yang bertujuan merancang dan merekam pembacaan cerita rakyat yang disertai dengan pelajaran bahasa Inggris untuk disiarkan melalui radio BBM.

Program PkM dengan judul "Pembelajaran Bahasa Inggris melalui Siaran Radio Komunitas Periode III” yang dilaksanakan pada tahun 2019 merupakan lanjutan kegiatan yang diselenggarakan pada tahun sebelumnya, yaitu penggunaan cerita rakyat untuk pembelajaran bahasa Inggris. Di samping itu, pada kegiatan ini diselenggarakan 
workshop untuk melatih siswa SMA/SMK menjadi penyiar program bahasa Inggris yang disiarkan melalui radio komunitas.

Kegiatan PkM 2019 diselenggarakan dengan tujuan mengoptimalkan pemanfaatan radio komunitas BBM sebagai sarana penyiaran program pelajaran bahasa Inggris. Sumber materi yang digunakan untuk program ini adalah cerita rakyat Indonesia yang sudah diterjemahkan ke dalam bahasa Inggris. Cerita rakyat dipilih sebagai sumber materi pembelajaran

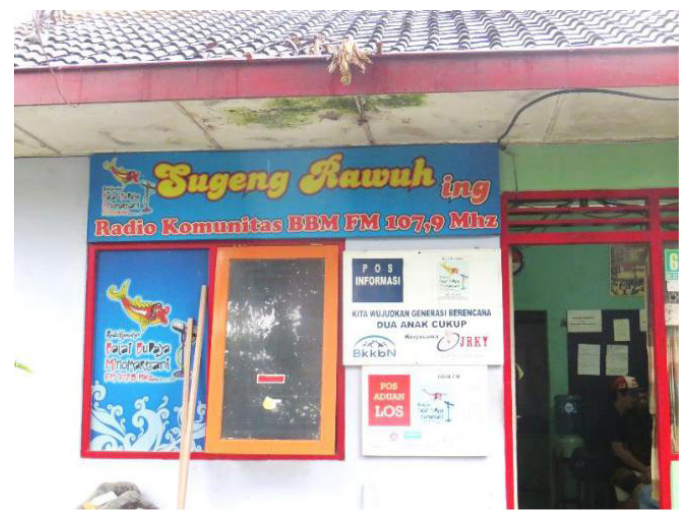

Gambar 1. Radio Komunitas Balai Budaya Minomartani FM 107,7 MHz berdasarkan sifatnya yang menyenangkan, menghibur, dan edukatif. Jika seorang pembelajar dihadapkan dengan materi ajar yang menarik dan berada dalam situasi yang nyaman dan menyenangkan, ia akan dengan lebih mudah dan lebih efektif menyerap materi ajar yang disampaikan.

Dengan adanya program pelajaran bahasa Inggris yang dikemas dalam bentuk storytelling, diharapkan dapat memotivasi siswa SMP dan SMA/SMK yang bermukim di Desa Minomartani dan sekitarnya untuk belajar bahasa Inggris. Selain meningkatkan kemampuan berbahasa Inggris mereka, manfaat lain dari kegiatan $\mathrm{PkM}$ ini adalah meningkatkan kreativitas dan keterampilan siswa sebagai penyiar program bahasa Inggris. Siswa juga dibekali dengan keterampilan mempersiapkan materi ajar bahasa Inggris dengan menggunakan cerita rakyat.

\section{Metode Pelaksanaan Kegiatan}

Metode yang dipakai dalam program pembelajaran bahasa Inggris yang disiarkan melalui radio komunitas BBM adalah storytelling dengan menggunakan cerita rakyat, antara lain, fabel, legenda, dan dongeng. Metode ini dipakai dalam pembelajaran bahasa Inggris karena beberapa alasan. Pertama, storytelling merupakan sarana komunikasi yang dalam hal ini merupakan sarana penyampaian pelajaran bahasa Inggris. Kedua, pada umumnya, orang senang bercerita dan mendengarkan cerita. Ketiga, melalui cerita, pendengar dapat meningkatkan keterampilan berbahasa seperti menyimak dan berbicara. Keempat, dengan metode ini, cerita akan menjadi lebih hidup dan menarik karena pembaca cerita mendramatisasinya sehingga membuat pendengar terlibat secara emosional serta merasa tertarik untuk tetap mengikuti apa yang disampaikan oleh pencerita.

Bercerita dapat dilakukan secara individu, berpasangan, ataupun berkelompok. Pencerita individu dapat membuat cerita menjadi menarik dengan memainkan volume suara (keras-pelannya), nada suara (tinggi-rendahnya), dan tempo suara (cepat-lambatnya). Pencerita yang terdiri lebih dari satu orang dapat berbagi peran. Dengan menggunakan metode storytelling, penyiar dapat membangkitkan imajinasi pendengar sehingga mereka mampu merasakan apa yang dialami oleh karakter dalam cerita tersebut. Dengan mendengarkan cerita, pendengar berada dalam keadaan yang tidak tertekan dan dalam suasana belajar yang nyaman sehingga mereka akan lebih mudah menyerap pelajaran yang disampaikan dan lebih termotivasi untuk belajar. 

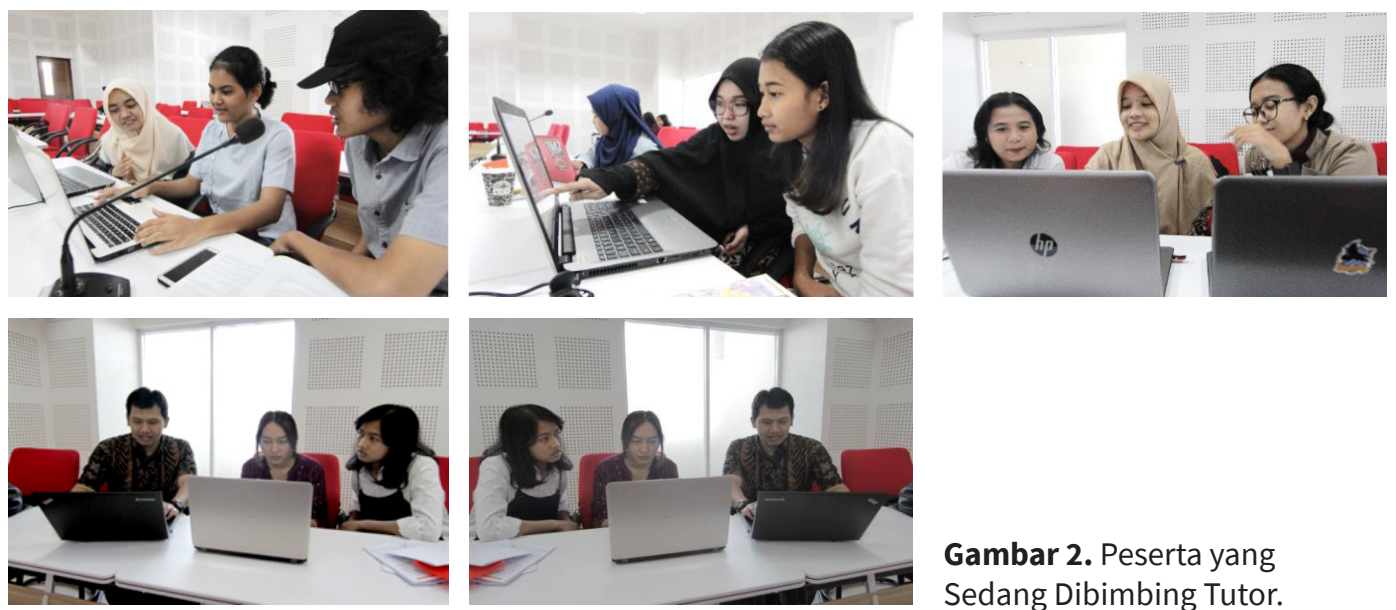

Gambar 2. Peserta yang Sedang Dibimbing Tutor.

Metode lain yang dipakai dalam workshop untuk melatih peserta sebagai penyiar program pengajaran bahasa Inggris adalah one-on-one coaching. Peserta dilatih secara berpasangan. Setiap pasangan didampingi oleh satu orang tutor yang membimbing mereka dalam hal mengubah teks menjadi naskah siaran; memilih dan menentukan unsur bahasa yang akan diajarkan; melatih pelafalan; dan mengatur nada, tempo, serta volume suara. Metode one-on-one coaching dipakai untuk memaksimalkan potensi peserta. Bimbingan yang diberikan bersifat intensif sehingga hasilnya lebih baik dan lebih cepat. Di tahap ini, peserta dilatih untuk berpikir kritis. Dalam proses one-on-one coaching, mereka diajak untuk menyampaikan gagasan-gagasan mereka sehingga ikut berperan aktif dalam menghasilkan audio script yang baik dan menarik. Pada proses ini, tutor berperan sebagai pemandu dan pembimbing. Tutor membantu peserta agar lebih fokus pada tujuan yang ingin mereka capai dan memberi masukan yang konstruktif.

\section{Pembahasan}

\section{Pembelajaran Melalui Radio}

Selain memberdayakan radio komunitas yang ada di Desa Minomartani untuk berbagai kegiatan, radio komunitas ini juga dapat digunakan sebagai sarana pembelajaran yang efektif. Radio adalah salah satu media komunikasi yang jangkauannya luas sehingga mudah diakses oleh banyak orang, baik untuk tujuan mendapatkan informasi maupun sebagai sarana hiburan.

Dengan melibatkan pendengar, radio dapat secara efektif membuat mereka tetap memperhatikan pesan-pesan yang disampaikan (ELT, 1979:9). Namun, perlu diingat pula bahwa pembelajaran berbasis multi-media, termasuk radio, bukan hanya lebih sulit direncanakan dan dilaksanakan, melainkan pembelajar juga tetap dituntut untuk berkonsentrasi (ELT, 1979:15). Oleh karena itu, selain materi siaran yang menarik, diperlukan juga penyiar yang mampu menyampaikan siaran dengan menarik pula sehingga pendengar akan tetap mengikuti siaran program tersebut.

\section{Penyiar Program Bahasa Inggris}

Tim PkM Prodi Sastra Inggris menganggap perlu materi pembelajaran disampaikan 
atau disiarkan oleh penyiar yang seusia dengan pendengar target, yaitu siswa SMP dan SMA/SMK. Penyiar yang dipilih adalah siswa SMA/SMK yang juga pembelajar bahasa Inggris. Mereka diharapkan dapat merasakan kesulitan belajar bahasa Inggris yang dihadapi pendengar seusia mereka. Dengan demikian, mereka dapat mencari cara menyampaikan materi dengan mudah dan menarik agar dapat memotivasi pendengar untuk belajar bahasa Inggris serta menyampaikan pesan bahwa belajar bahasa Inggris tidak sulit.

Memberdayakan siswa SMA/SMK yang tinggal di Desa Minomartani untuk menjadi penyiar di radio komunitas ini adalah salah satu upaya mengoptimalkan sumber daya manusia yang ada di Desa Minomartani untuk menjadi pengisi acara sekaligus operator di radio komunitas. Dengan demikian, diharapkan ada keberlanjutan program siaran pembelajaran bahasa Inggris melalui radio komunitas.

Agar program ini tetap berlanjut, yang dipilih untuk menyiarkan program ini adalah siswa SMA/SMK yang bermukim di Desa Minomartani yang tertarik dan ingin belajar tentang penyiaran. Sebagai warga Desa Minomartani, mereka diharapkan dapat berkomitmen untuk tetap melanjutkan program ini yang target pendengarnya adalah siswa SMP dan SMA/SMK yang tinggal di Desa Minomartani. Ini sesuai dengan semboyan radio komunitas, yaitu dari, oleh, dan untuk komunitas.

\section{Pembelajaran Bahasa Melalui Cerita Rakyat}

Dipilihnya cerita rakyat Indonesia yang telah diterjemahkan ke dalam bahasa Inggris sebagai sumber materi pembelajaran bahasa Inggris melalui radio komunitas berdasarkan beberapa faktor. Faktor pertama seperti yang disampaikan oleh Bean (1999), yakni cerita rakyat merupakan salah satu sarana yang paling mudah diakses untuk pembelajaran bahasa. Berdasarkan pendapat ini, dapat disimpulkan bahwa karena jumlahnya yang sangat banyak, cerita rakyat mudah dicari untuk dipilih sesuai tujuan pembelajaran dan minat siswa. Faktor kedua, cerita rakyat dipilih atas dasar yang disampaikan oleh Taylor (via Lwin, 2015), yaitu tema-tema cerita rakyat seperti kejujuran, kebaikan, iri hati, dan tamak sangat akrab dengan telinga pendengar. Karena sudah mengenali cerita-cerita rakyat beserta tema-temanya, beban pendengar dalam memahami jalan cerita berkurang sehingga mereka dapat lebih fokus pada aspek-aspek kebahasaan yang akan dipelajari. Faktor ketiga, karena siaran radio komunitas BBM sudah berbasis internet sehingga siaran ini dapat didengarkan di seluruh dunia sehingga menjadi sarana promosi cerita rakyat Indonesia. Hal ini merupakan upaya yang sangat baik untuk melestarikan dan mengenalkan cerita-cerita rakyat Indonesia ke dunia internasional.

Selain beberapa faktor di atas, pemilihan cerita rakyat sebagai bahan ajar juga dapat mendorong imajinasi pendengar dan kreativitas pembuat bahan ajar. Lwin (2015) berpendapat bahwa cerita rakyat yang telah diterjemahkan ke dalam bahasa Inggris sangat bermanfaat untuk pembelajar pemula dalam mempelajari tata bahasa seperti simple present dan simple past tenses serta kata sambung seperti and dan but. Karena sifatnya adalah tradisi lisan, bahasa yang dipakai dalam cerita rakyat lebih sederhana daripada tulisan akademik sehingga lebih mudah difahami.

\section{Tahap-tahap Pelaksanaan untuk Mencapai Tujuan PkM}

Pelaksanaan PkM Prodi Sastra Inggris periode Mei-Juli 2019 terdiri atas beberapa tahap. 
Dalam mencapai tujuan, tim PkM Prodi Sastra Inggris melaksanakan serangkaian kegiatan berupa persiapan, perancangan dan penyusunan modul dan workshop.

\section{Persiapan}

Pada tahap persiapan, tim PkM Prodi Sastra Inggris mengadakan pertemuan dengan pengurus BBM untuk membahas kerja sama yang akan dijalin. Pada pertemuan tersebut disepakati waktu, tempat, materi, dan peserta workshop. Pada tahap ini Prodi Sastra Inggris bekerja sama dengan IMAJI (Ikatan Mahasiswa Jurusan Sastra Inggris) mengadakan rekrutmen mahasiswa. Delapan mahasiswa yang direkrut bertugas untuk membantu kegiatan workshop sebagai penerima tamu, seksi perlengkapan, konsumsi, dan dokumentasi.

\section{Perancangan dan Penyusunan Modul}

Tahap kedua adalah perancangan dan pembuatan modul pelatihan yang berjudul "Training Module: Teaching English through Radio Storytelling" oleh tim di bawah koordinasi dan bimbingan Mala Hernawati, S.S., M.A. Modul Pelatihan ini berisi materi Why Teach English Through Storytelling, Why Local Folklores? Transforming Stories into Teaching Materials, contoh teks cerita asli dan yang telah dimodifikasi untuk tujuan pembelajaran, contoh audio script, dan beberapa cerita rakyat.

Seperti yang dikatakan Brewster et al. (2002:2), belajar bahasa melalui cerita rakyat dapat memperkuat pengetahuan dasar fungsi dan struktur bahasa, kosakata, dan keterampilan belajar bahasa. Ini sesuai dengan tujuan program $\mathrm{PkM}$ Prodi Sastra Inggris, yaitu pembelajaran bahasa Inggris melalui cerita rakyat. Cerita rakyat yang dipilih oleh tim, antara lain, adalah

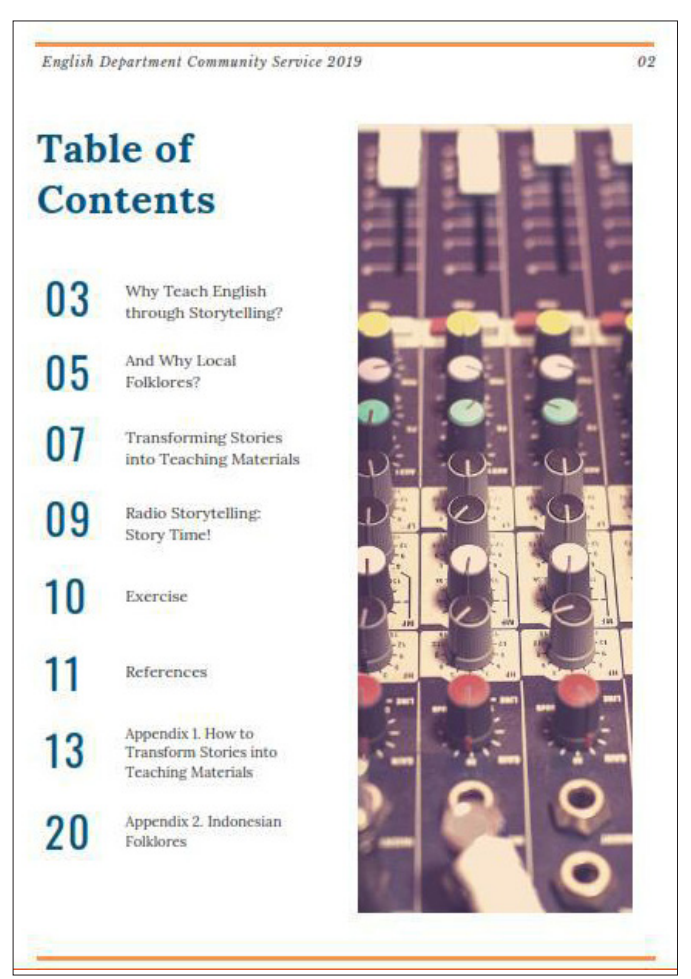

Gambar 3. Daftar Isi Modul Pelatihan. Cindelaras, Kancil Steals Cucumber, Timun Mas, Bawang Merah and Bawang Putih, Buffalo's Victory, How Rice Grows in the Wet Rice Field, Lutung Kasarung and Purbasari, Malin Kundang, Kancil and Tiger, Baruklinting, The Golden Snail, The Legend of Surabaya, Ajisaka's Turban, The True Strength of Patih Senggilur, Takatuliangs Lover (http://folklore-lover.blogspot.com) (Suyenaga, 2005). Semua cerita rakyat ini mempunyai pesan moral yang mengajarkan kebaikan melawan keburukan serta memberi contoh perilaku atau karakter yang baik dan yang kurang baik. Tim PkM berharap agar pendengar muda, khususnya, dapat belajar tentang standar moral dan nilai yang dapat menjadi pedoman hidup mereka.

Tim pembuat modul kemudian memilih dan membuat contoh cara mengubah cerita rakyat terpilih menjadi bahan siaran. Pertama, cerita rakyat asli diubah dengan menyesuaikan panjang waktu siaran (kurang lebih 45 menit) dengan mempertimbangkan 
materi-materi siaran lainnya, misalnya pembuka acara, lagu-lagu pengisi, narasi penyiar, dan bahan ajar. Cerita rakyat menjadi lebih pendek, tetapi tidak kehilangan inti cerita ataupun unsur-unsur yang digunakan untuk materi ajar.

Ada tiga hal yang perlu diperhatikan dalam memanfaatkan cerita rakyat menjadi materi pembelajaran, yaitu (a) tujuan pembelajaran yang jelas, (b) cerita yang dipilih telah dikenal dan relevan, dan (c) penyesuaian cerita yang tepat, yaitu dengan cara menyederhanakan, mengubah, serta menambah atau mengganti kata/ekspresi. Mengingat sasaran pembelajar adalah siswa SMP dan SMA/SMK, unsur bahasa yang dipilih dan disampaikan tidak yang rumit, misalnya kosakata yang berkaitan dengan kata sifat dan kata benda serta aspek gramatika sederhana misalnya, present atau past tenses.

\section{Workshop}

Untuk mempersiapkan penyiar program pembelajaran bahasa Inggris melalui radio komunitas BBM, diselenggarakan workshop selama dua hari dengan diisi oleh narasumber yang kompeten dalam bidang penyiaran dan pendidikan. Pada workshop pertama, yakni Sabtu, 29 Juni 2019, ada empat narasumber yang menyampaikan materi yang berkaitan dengan penyiaran program pengajaran bahasa Inggris. Narasumber pertama, Dr. Eddy Pursubaryanto, M.Hum. menyampaikan materi tentang prinsip dan teknik bercerita. Disampaikan bahwa dalam bercerita, ada beberapa hal yang mempengaruhi cara seseorang bercerita, antara lain, siapa pendengarnya, bahasa apa yang digunakan, musik atau lagu pengiring yang dipilih, waktu yang disediakan, dan jumlah tokoh yang terdapat dalam cerita tersebut. Pada waktu menyampaikan materi, narasumber meminta peserta secara spontan menunjukkan kebolehan mereka bercerita tentang pengalaman mereka atau tentang tokoh wayang binatang yang mereka pilih.

Narasumber kedua, Drs. Tri Giovanni menyampaikan cara menggunakan mikrofon dan menulis naskah. Narasumber menyampaikan kelebihan penggunaan radio sebagai media siaran, cara menulis naskah untuk radio, cara merekam suara dan memperkenalkan terminologi yang dipakai dalam produksi, antara lain, music in, music out, MVO (male voice over) dan FVO (female voice over). Di samping itu, narasumber juga menyampaikan jenis-jenis mikrofon seperti Omni-directional Microphone yang mampu menangkap suara dari segala arah, Bi-directional Microphone yang mampu menangkap suara dari dua arah, dan Uni-directional Microphone yang mampu menangkap suara hanya satu arah di depannya.

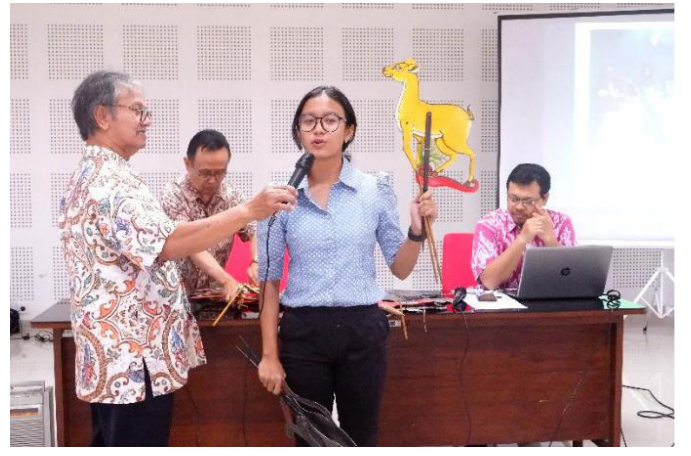

Gambar 4. Peserta Sedang Bercerita dengan Media Wayang Binatang.

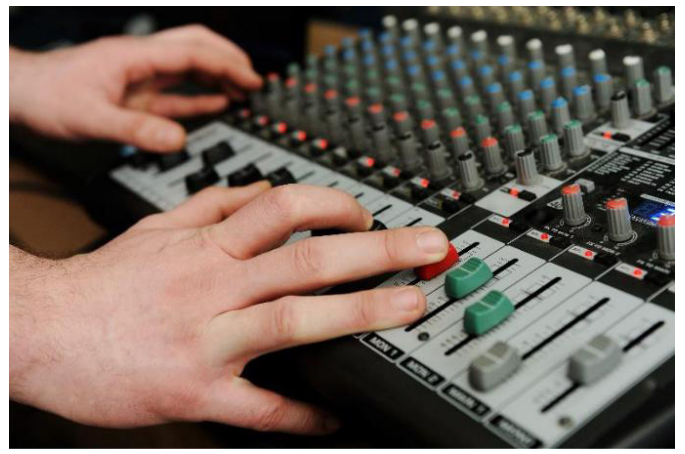

Gambar 5. Audiomixer. 

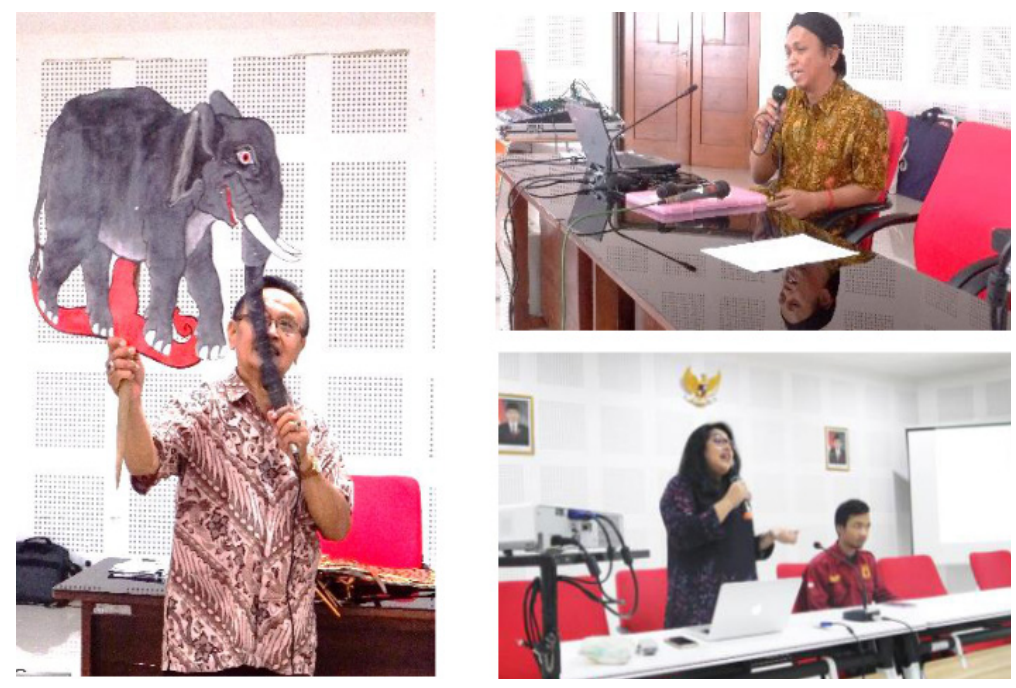

Gambar 6. Narasumber Menyampaikan Materi.

Narasumber ketiga, Sri Kuncoro menyampaikan cara mengoperasikan audio mixer, yaitu alat elektronik pencampur suara yang masuk dari alat musik atau mikrofon. Alat ini terdiri atas dua jenis, yaitu analog dan digital.

Narasumber keempat, Dr. Adi Sutrisno, M.A. menyampaikan tentang perhatian pendengar, yaitu lama waktu seorang pendengar mampu fokus pada siaran; segmentasi pendengar; dua tipe pembelajar, yaitu global dan sequential; mode komunikasi interaksional dan transaksional; serta tiga tipe perhatian yang terdiri atas visual, auditory, dan kinesthetic.

Pada workshop hari kedua, Sabtu, 6 Juli 2019, sesi pertama diisi oleh narasumber, Mala Hernawati, S.S., M.A. yang menyampaikan tentang praktik pembuatan bahan ajar dan diikuti dengan sesi one-on-one coaching. Pada sesi one-on-one coaching, peserta diberi tugas group project untuk memilih salah satu cerita rakyat yang terdapat di dalam modul pelatihan. Setelah itu, mereka diminta untuk mentransformasikan cerita yang telah mereka pilih untuk menjadi materi ajar. Dalam proses ini, peserta boleh melakukan perubahan pada cerita tersebut seperti menyederhanakan cerita atau memodifikasi cerita dengan cara, misalnya, mengganti kata yang terlalu sulit dengan kata yang lebih mudah. Salah satu contoh adalah dalam cerita Bawang Merah and Bawang Putih terdapat katakata seperti household chores yang dapat diganti dengan kata yang lebih mudah dipahami seperti housework dan kata venomous yang dapat diganti dengan kata poisonous. Cara kedua yang dapat dilakukan peserta adalah dengan menambahkan kata-kata, frasa, atau kalimat untuk memperjelas arti sebuah kata, misalnya The mother and Bawang Merah were cruel towards Bawang Putih. Untuk memudahkan pemahaman kata cruel, peserta dapat menambahkan sebuah kalimat, misalnya The mother and Bawang Merah were cruel towards Bawang Putih. They treated her very badly. Kalimat tambahan ini memperjelas arti kata cruel.

Untuk mentransformasi cerita rakyat menjadi bahan ajar, peserta dibatasi pada tiga topik: descriptive adjective, comparison, dan regular and irregular verbs. Setelah memilih topik untuk diajarkan, peserta harus menyiapkan audio script yang akan dipakai unuk siaran radio. Peserta juga harus mempertimbangkan durasi cerita dan pembahasan 


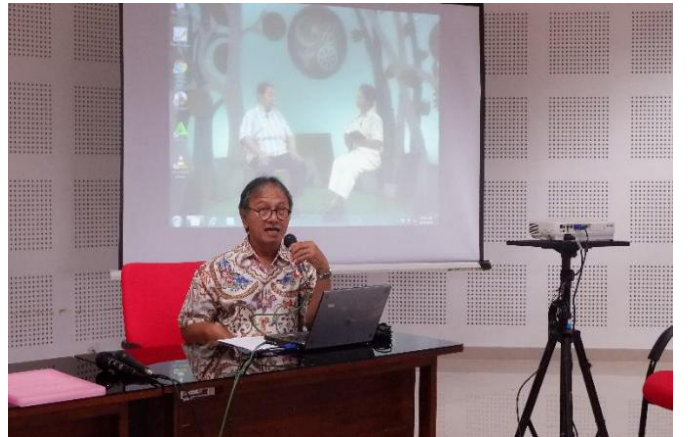

Gambar 7. Narasumber Memberi Feedback.

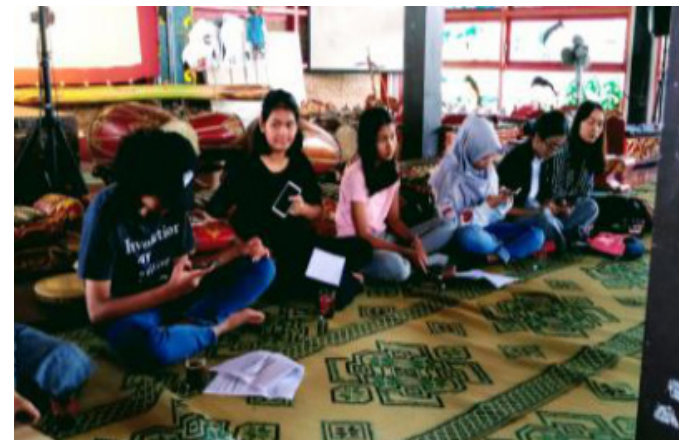

Gambar 8. Penutupan di Balai Budaya Minomartani.

topik agar tidak terlalu panjang sehingga dapat mempertahankan perhatian pendengar. Untuk proses pemilihan cerita, pemilihan topik untuk materi ajar, dan penulisan audio script, masing-masing pasangan peserta didampingi oleh satu orang tutor. Di bawah bimbingan tutor, peserta berlatih membaca audio script. Setelah merasa yakin dengan cara bercerita dan menyampaikan topik pembelajaran, mereka membaca audio script sambil direkam untuk kemudian didengarkan kembali bersama-sama. Narasumber kemudian memberi komentar dan saran perbaikan.

Pada pertemuan terakhir, yakni Sabtu, 13 Juli 2019 di Balai Budaya Minomartani, pembacaan audio script yang telah direkam disiarkan secara live streaming.

\section{Luaran Kegiatan PkM}

Luaran kegiatan PkM Prodi Sastra Inggris berupa audio script, modul pembelajaran, laporan kegiatan, artikel, foto-foto dan kegiatan workshop yang telah direkam secara audiovisual. Dengan tersedianya rekaman ini diharapkan dapat dimanfaatkan oleh pengelola radio komunitas BBM di Desa Minomartani untuk menyelenggarakan workshop serupa untuk calon-calon penyiar yang lain. Siswa ataupun guru yang bermukim di sekitar Desa Minomartani dapat memanfaatkan materi ajar untuk mengadakan pelatihan secara mandiri. Namun, tidak menutup kemungkinan kedua belah pihak, baik pengurus radio komunitas BBM maupun tim PkM Prodi Sastra Inggris, untuk melanjutkan kerja sama dalam proses pelatihan dan pemanfaatan bahan ajar tersebut guna melatih generasi penyiar berikutnya. Ketersediaan Training Module yang didalamnya terdapat materi siaran dan bahan ajar dapat dimanfaatkan oleh penyiar-penyiar baru sebagai buku pegangan mereka.

\section{Penutup}

Tantangan yang dihadapi tim PkM Prodi Sastra Inggris dalam melaksanakan kegiatan adalah (a) kemampuan bahasa Inggris peserta yang tidak setara; (b) alokasi waktu yang kurang bagi peserta untuk berlatih sebagai penyiar maupun sebagai operator.

Untuk mengatasi masalah pertama, tim PkM Prodi Sastra Inggris akan mengantisipasi pada pelatihan selanjutnya dengan memilih peserta melalui interview, sedangkan untuk masalah kedua dapat diatasi dengan memperpanjang waktu pelatihan. Melihat minat 
dan antusiasme peserta yang sangat tinggi, perpanjangan waktu untuk pelatihan tidak akan menjadi masalah bagi mereka. Di samping itu, latihan tidak hanya dilaksanakan di Fakultas Ilmu Budaya, tetapi juga di Balai Budaya Minomartani karena peralatan siaran radio terdapat di sana.

Apabila tingkat keberhasilan program $\mathrm{PkM}$ diukur berdasarkan ketercapaian tujuan dan kesesuaian perencanaan, dapat dikatakan bahwa tim PkM telah berhasil dalam hal ini. Semua materi yang disampaikan oleh narasumber tersampaikan dengan sangat baik, menarik dan jelas. Kehadiran seluruh peserta tetap terjaga hingga akhir workshop. Peserta selalu hadir tepat waktu dan sangat aktif mengikuti seluruh rangkaian kegiatan. Demikian pula pada sesi terakhir, yakni Sabtu, 13 Juli 2019, semua peserta hadir di Balai Budaya Minomartani untuk siaran live streaming. Peserta memberikan tanggapan yang sangat positif terhadap kegiatan ini dalam wawancara yang dilakukan oleh pengelola Radio Komunitas BBM, yang disiarkan secara live streaming.

Kemanfaatan kegiatan ini adalah meningkatkan minat belajar bahasa Inggris pendengar radio komunitas, khususnya siswa SMP dan SMA/SMK; meningkatkan keterampilan menyiarkan materi pembelajaran bahasa Inggris melalui siaran radio; dan memberdayakan masyarakat dalam memanfaatkan radio komunitas BBM. Kemahiran siswa SMP dan SMA/SMK Desa Minomartani dalam menguasai bahasa Inggris yang diperoleh melalui program ini diharapkan dapat meningkatkan kemampuan mereka dalam berinteraksi dengan tamu-tamu asing yang berkunjung ke Balai Budaya Minomartani yang merupakan pusat kegiatan seni dan budaya.

\section{Referensi}

Bean, M. (1999). "The Role of Traditional Sories in Language Teaching and Learning” dalam Traditional Story Telling Today: an International Source Book. London: Fitzroy Dearborn.

Brewster, J. E. (2002). The Primary English Teacher's Guide. New England: Pearson Education.

ELT, M.I. (1979). The Use of the Media in English Language Teaching. London: British Council.

Lwin, S. (2015). "Using Folktales for Languge Teaching" dalam The English Teacher.

Suyenaga, J. (2005). Indonesian's Children's Favorite Stories. Turtle Publishing.

\section{Daftar Laman}

http://folklore-lover.blogspot.com. (n.d.). 